「䄉維ルネッサンスの新潮流」特集

\title{
ノースカロライナ州立大学における産学協同 あるケーススタディ
}

\author{
D. R. ブッキャナン
}

\section{1. 大学・企業における研究価値観の変化}

近年, 米国においては, 新しい形の産学協同が推進さ れてきた。その進捗状況を，ノースカロライナ州立大学 を例にとって説明し，その成功の原因を分析するのが, 本講演の主旨である。

産学協同は，いずれの国においても大きな問題であっ た。その原因の主な一つは（少なくともごく最近まで は)，大学と企業での価値観の違いにある。例えば，大 学・企業双方に興味があり, 利益になる研究とは何か。 大学の研究者にとっておもしろい研究テーマは，企業に とっては価値がない，ということが往々にしてある。大 学の研究テーマは個人的なものであるが, 企業において は総合的・グループ的でなければならない。重要な規模 の大きい研究プロジェクトにどの様に取り組むか, 時間 的な制約は，といったことも，大学と企業ではかなりの 違いがある。企業では「時間」が研究の価値を決める重 要なファクターであるが, 大学では研究の「質」がより 重要である。表 1 に, 大学・企業でこれまで伝統的に考 えられてきた研究の価値基準をまとめた。大学では, 基 礎的な研究をより重要と考えており，基礎研究が学問的 伝統となっている。企業は当然応用開発研究を目的とし た短期プロジェクトに興味を持っている。逆にいえば, 企業にとって如何に重要であろうと, 大学は応用開発研 究をどの様に進めて行くか理解できない。大学は何世紀 も前から続く古い学問的伝統の上に存在しているが, 企 業は学問的伝統にはあまり興味がない。「学生の教育」 は大学の使命の一つであるが, 企業にとってはさほど重 要ではない。 2,3 年前までは, 米国の大学は特許にあ まり関心を示さなかった。特許は大学の伝統と相容れな いものであった。特許は企業にとっては非常に重要であ
ることはいうまでもない。時間との競争に明け暮れる企 業と違い，大学は「ゆったりとした処」であり，大学教 授は時間のことなど気にしない。最後に，大学における 研究は，一人の教授と，その研究に携わる $2 ， 3$ 人の大 学院生により性格が決まるが，企業における研究の特色 は，複雑な問題をチームで取り組むところにある。つま り，大学と企業においては研究価值は同じではなく，お 互いの価値観がそれぞれ意味があるということを認めよ うとしなかった。

この状況は，今特に米国において，変わりつつある。 表 2 は，お互いの価傎観がどの様に変わってきたかを示 しているが，その変化は，大学・企業いずれにも見受け られる。少なくとも米国の企業は，大学における基礎研 究の重要さを認めつつある。1980年代における景気後退 のため, 米国企業は基整研究遂行の余裕を失い, 大学が 基礎研究を行うべきだと考元始めた。大学側も, 自分達 の研究が社会の利益になるなら，企業に移行すべきであ

表 1 大学・企業における研究の価値基準（伝統的）

\section{Traditional University/Industry Research Values}

\begin{tabular}{lccc} 
Value of: & University & Industry \\
\cline { 3 - 3 } Basic Research & Great & Little \\
Appl. Research & Little & Great \\
Scholarship & Great & Little \\
Student Educ. & Great & Some \\
Patents & None & Great \\
Time & Little & Great \\
Interdis. Teams & None & Great
\end{tabular}

University/Industry Cooperation at North Carolina State University: Some Case Studies 筆者紹介 DAVID R. BUCHANAN

College of Textile, North Carolina State University

ノースカロライナ州立大学栈維学部長, 教授

本稿は昨年 9 月 30 日, 軽井沢プレシンポジウムでの講演内容を, 京都工芸織維大学工芸学部・梶原莞爾 助教授がまとめられた。 
表 2 大学・企業におりる研究の価値基準（現在変化中）

\section{New University/Industry Research Values}

\begin{tabular}{lcc} 
Value of: & University & Industry \\
\cline { 3 - 3 } Basic Research & Great & Increased \\
Appl. Research & Increased & Great \\
Scholarship & Great & Increased \\
Student Educ. & Great & Increased \\
Patents & Great & Great \\
Time & Increased & Great \\
Interdis. Teams & Increased & Great
\end{tabular}

る，ということを理解し始めた。

企業も，大学の研究伝統により深い理解を示すように なっているし，企業の将来を担う学生の教育の重要さを 真别に考えるようになった。企業は, 現在の技術しベル に即した教育の必要性を痛感している。

最も興味ある変化恃大学における特許に对する考元方 で，今では大学においても企業におけると同様に，特許 を価値のある研究成果として認めだした。今後産学協同 においては，その研究プロジェクトから生まれる特許の 取扱いについてよく協議をし，同意を得ていることが必 要になる。

大学も時間の重要性を次第に認識するようになってい る。研究プロジェクトに対し，ある定められた研究期間 を設定するようになってきたが，これは企業にとって望 ましい変化である。

最も重要な変化は, 大学の教授達が学際的な研究チー ムを組んで研究をするシステムに慣れてきたことである。 つまり，個人ができる研究の規模を淩鴐する大規模な研 究プロジェクトを共同で遂行できるようになってきた。

現在米国においては, 企業は大学の研究能力, 大学の 持つ知識を必要としているし，大学は社会に对する有用 性を企業とのかかわり合いで証明しようとしている。

この様な変化を総括すると, 米国では現在, 大学及び 企業の価値観は次第に似通ったものになってきているこ とに気づく。これは非常に重要な結果であり，特に大学 はこの価値観の変化がもたらす意味を理解しなければな らない。言い替えると，価値観の変化を理解して始めて， 大学の未来に希望を持つことができる。

\section{2. 米国の大学システムーノースカロライナ州立大} 学晹椎学部の例

米国の大学のシステムには，「ランドグランド（土地 基金) 大学」という伝統がある。この伝統が，今日の効 果的な産学協同のモデルとなる。このユニークな米国の

「土地基金大学」(ノースカロライ十州立大学もその一 例である）という組織は，1860年代に合采国政府により 確立された。合衆国政府は，50の州に土地を下付し，各 州はその土地を売却した資金を基に大学を設置すること を決めた。但しこれらの大学は，既にあるハーバード， イェールといった私立大学と異なった性格を持つ。当時 の米国においては，富裕な社会的地位の高い限られた階 級の子弟しか大学教育を受けることができなかった。 「土地基金大学」は，労㗢者階級の子弟の教育を目的の 一つにしている。更に，教育は実務的であることを特幾 として拐り，当時の記録によると，「農業，機械工作」 と記されているが、現在では「農業、エンジニアリン グ」と読み替えられている。これは，米国におけるそれ までの教育理念に大きな変革をもたらした。教育の義務 に加えて，研究に対する要請もある。大学であるから， 研究はもちろんアカデミックでなければならないが，そ の研究が同時に社会，つまり米国民並びに州の経済，の 益にならなければならない。この事は，「土地基金大学」 における研究が，伝統的な大学に扔ける研究に比べて, より害務的な方向に向くことを意味する。典型的な例は 農業で，この方面における研究の成果により，米国は世 界で最も奻率の良い農業生産国となった。

「土地基金大学」には実は第 3 の要請がある。この要 請は「拡張」と呼ばれている。「拡張」とは，大学で培 われた知識を大学の外の世界へ持ち出すことであり，大 学の外の世界とは，その州の企業，州民を意味する。

「拡張」とは即ち「大学から飛び出す」ことであり，

「技術移行」である。

現在「土地基金大学」は合衆国の各50州にそれぞれあ り，ノースカロライナ州立大学はその一つである。これ らの大学には，農業コース，エンジニアリングコース， 工学コースが必ずあり，㦵維が重要な産業である州の

「土地基金大学」には䄉維工学コースが用意されている。

ここで述べたところから明らかなように，ノースカロ ライナ州立大学には 3 つの莪務が科せられている。学生 の特に実務的な分野の教育，ノースカロライナ州社会に 役立つ研究，大学で得られた知識の企業への移行，の3 つである。1991年 1月に開設されたノースカロライナ州 立大学䄉維学部の新しい施設は，近代的な「土地基金大 学」のモデルである。この施設は，「土地基金大学」と 
しての使命を遂行する上で，线維学部が大きく前進した ことを象徴している。現在，ノースカロライナ州立大学 峨維学部は，西欧世界では最大の峨維関連教育研究機関

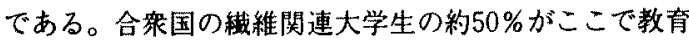
を受けている。䄉維学部の年間予算は千四百万ドルを超 えるが，その内ノースカロライナ州から支給されるのは 1/3に過ぎない。その他は，合采国政府及び企業からの 研究費である。峨維学部は伝統的にノースカロライナ州 の䄉維企業と絮密な関係にあったが，現在では更にその

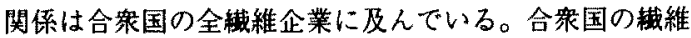
関連の博士課程の学生の $2 / 3$ は, ノースカロライナ州立 大学生であり，またノースカロライナ州立大学樴維学部 は峨維関連教育研究に対して世界で最もバランスがとれ た「総合的」なプログラムを持っている。総合的という ことは，まず原料の高分子に始まり，紡糸，紡績，織布， 染色仕上げ，䋖製、コンポジット，流通に至るまで，䄉 䧽産業にとって重要な項目は全て網睢している。同様に 学部学生の教育も棇合的な見地加らなされ，化学，物理， 数学および械維工学基磉を学ぶことが要請されており， 将来，デザイナーになるにせよ，経営者になるにせよ， 化学を専攻するにせよ，エンジニアになるにせよ，共通 したバックグランドを有することになる。この新しい轹 維学部の施設には，効率よく総合的な峨維教育・研究を 遂行できるよう，最新の設備が整っている。

ノースカロラナイ州は 2 千 7 百万ドルを建物の建設哄 に，更に 6 百万ドルを設備費と新轿維学部用子算に計上 したが，現在の見模の設備を整えるためには充分ではな く，日本の企業を含む峨維企業，機械メーカーが寄付金 あるいは装置寄付という形で 1 千 4 百万ドルを負担した。 建物床面積は30万平方フィートで，旧䄉維学部に比べて 約 $40 \%$ 增加しており，教育，研究は勿論のこと，「拡張」 活動も全て同一の建物内でできる。

新織維学部が最も誇りにしている施設は，モデル製造 設徣と呼んでいる䄉維プロセス寒験室である。この施設 は䄉維教育・研究の分野で最も最新の設備を備えたブロ セス実験施設で、ここの85\%の饿維プロセス用装置, 設 借が新峨維学部を建設する機会に更新された。モデル製 造設備は，溶融紡系，フィラメント・ヤーン，ショート スティプル，紡績，ニット，不織布，染色・仕上げ，ア パレル製造, 物性湘定, コンピューターを核として設備 内の全ての装置を有機的に結び付け制御するマネージメ ント情報，の分野で構成され，ここにある全ての設備を 利用して，ノースカロライナ州立大学桟䧽学部の $3 つ の$ 活動，「教育，研究，应張」，在機能的に遂行している。 この新しい設備のおかげで，傤維学部の教育・研究ナ ログラムを拡大する事が可能となり，例えば学部学生数
は960名と，3 年前に比べ200名增大した。学部学生は, マネージメント, 轹維工学, 物質科学, エンジニアリン ダ, 化学, のコースに分けられ。(2，3名コース所属の 決まらないものもいる)，それぞのコースの学士号を取 得することになるが, 科学, 数学, 轿維工学の 3 教科は 全学生に共通した必修科目になっている。

大学院学生数も急激に增加した。3 年前には90名であ ったが, 現在は154名になっており，内半数が修士課程, 残りは阵維・高分子科学専攻博士課程, 並びに新しい博 士課程, 峨維工学・経営学尃攻 (工学とビジス, 経済 学を組み合わせたプログラム) の学生である。䄉維学部 の研究が学際的であることを反映して，かなりの数の修 士課程の学生は他学部出身者である。

研究基金も增加した。樴䧽学部の研究はある特定の目 的を持っている。それは，ただ単なる械維関連知識の修 得に留まらず，新しい械維学部の創設理念の実践的証明 として大学院学生を育成することである。

较維学部の研究は，大きく 4 つの分野，物質科学（高 分子, 荗維素材)，デザイン(製品デザイン, プロセス デザイン），製造（最新の織維工学, 自動化，コンピュ ーター管理)，システムに分けることができる。システ 么研究分野とは，峨維，布帛，アパレル，流通の複合が 真の産業であるとする考え方で，䄉維産業とは，紡系， 紡嚗，觡製，染色・仕上げ，流通の各部門が個々に独立 した産業の絵称ではなく，それらが一体となったもので あり, 各部門間の相互作用が樴維産業にとって最も重要 となる。

\section{3. 椣椎関連研究の功向}

ここ $2 ， 3$ 年の間に，全国組織の樴維研究センターが 設立され，いくつかの大型研究プロジェクが動きだし た。全国㖪維センターは，合穼国商務省基金により設立 され，不織布協同研究センターは米国科学盰団と25の企 業の基金により設立, MARS プロジェクト(コンポジッ 卜研究)はNASA（米国宇宙局）、コンピュータ一管理 ・制御製造システム研究プロジェクトはIBMを中心と 寸るいろいろな分野の企業, 新規電子技術開発研究プロ ジェクトは複数企業グループ，高熱用保讙服・快適衣服 研究七ンターはデュポンを中心とする䙓数企業, がスポ ンサーになっている。その他ノースカロライナ州政府基 金による研究プロジェクトもあり，伝統的な個々の研究 者のプロジェクトは企業，合衆国政府がスポンサーにな っている。

ここに挙げたプロジェクトの多くは，学際的であり， いろいろな研究分野の研究者, 学生がタループとして関 与している。これにより，挠維学部が受け取る研究基金 
の積が飛躍的に增大した。1972年から1992年までの研究 基金の積の流れを見ると，この $2 ， 3$ 年の增加が最も大 きく，1992年にはその額は 6 百万ドルに達している。こ の研究基金增大の率は，ノースカロライナ州立大学の中 で䄉維学部が最も高く，10年前に比べるとほは14倍にな っている。その結果として研究活動も活発化した。

教育・研究の活発化は望ましいことであるが、「土地 基金大学」として，得られた研究結果を社会に還元する 義務がある。ノースカロライナ州立大学樴維学部の「桩 張」プログラムは専属スタッフと学部スタッフの協同て 連営されている。「拡張」プロダラムの教育コースは 2 種類ある。一つは企業向け短期コース（3４日コー ス）で，昨年度は16コース開催し，1，300名が参加した。 インプラントコース（工場内コース）と呼ぶ，特定の企 業用に開発した企業の敷地内で開催する短期教育コース もあり，昨年度は23コース500名の参加があった。

「应張」プログラムには「応用研究」活動もある。こ れは，大学の施設を利用して，企業と協同で開発・応用 研究を行うもので, 大学にとっては企業とコンタクトを 持つ良い機会であり，モデル製造設備ができ始めてこの 活動が可能となった。「応用研究」ブログラムの目的は， 「技術移行」「「企業への奉仕」（直接の奉仕ではなく， 実務経験のある学生を育成し企業の即戦力となる人材を 供給する）と，モデル製造設䚚の更新資金を得ることも 兼机ている。日本と同じようにノースカロライナ州でも， 装置を更新する資金の調達は難しいが，㧴維技術の分野 では企業に役に立つ技術者を育てるためには，䑨えず最 先端の装置が稼䣸していなければならない。

一般的な「応用研究」分野での活動は，ブロセス評価 と開発，製品評価と開発，物性テストと品質管理，ノ一 スカロライナ州立大学縺維学部の研究室から企業の研究 室への基本的な研究結果の移行が含まれる。この場合， 研究に対する考え方としては，学問として優れているか， あるいはどの程度工業的に応用できるかの二つがある。 伝統的な大学研究は，「学問的」でなけ机ばならないが, あまり応用には期待できない。ノースカロライナ州立大 学䄉維学部の伝統的な「拡張」プログラム, 例えば短期 教育コース，は非常に応用的であったが、レベルとして は低かった。「応用研究」プログラムはこのギャッブを 埋める目的で出発した。戟維学部では，応用可能であり， 且つ学問的にも優れている研究を遂行し，企業に移行で きる結果を得たいと考えている。

\section{4. 全国数維センター}

これまで述べた教育・研究・搪張活動は、「土地基金 大学」としての義䅂を遂行するノースカロライナ州立大
学樴維学部の活動の第一段階である。この活動を通じて， 企業とより密接な協力関保を結ぶことが，研究能力の面 からも，設備・人材の面からも，可能になった。必然的 に第二段階の，より大規模な産学協同体制，「全国縺維 センター (National Textile Center)」，の設立になった。 「全国峨維センター」の設立は，1986，87，88年頃のノ 一スカロライナ州立大学樴維学部の活動にそのルーッが ある。その当時轹維学部は米国科学財団に、「エンジニ アリング研究センター」を設立するため，多額の予算を 申請した。この研究センター構想は合策国政府関連の機 関に予算を申請したものの中ではユニークなもので, 一 つ一つのテクノロジーではなく，いろいろな産業で独立 に開発されてきたテクノロジーをそれぞれ相関した椱合 体として考えようというものであった。この申請は好意 を持って受け付けられ，1987，88年には政府の係官が視 察に来るほどで，米国科学財団の予算順位の最終リス卜 10位内に入っていたここの申請で最も成果があったのは， 申請準備の段階で多くの企業と接触し，協同で申請書を 作成し，研究センタープロダラムについて意見交換し， 予算申請準備段階で初期の研究に必要な経乑 60 万ドルを センター基金として得たことであった。このとき糃維学 部と工学部を中心とした学際的な研究チームが発足した。 結果的には，この申請は却下され，コンピューター，マ イクロエレクトロニクスが予算を得た。しかし企業から 得た60万ドルの基金を基に、CRAFTM (Consortiun for Research in Apparel, Fiber, Textile Manufacturing) 䅧し，米国科学財団に申請した研究プロジェクトの内 3 つのプロジェクトを 3 年の期間遂行することにした。

(実の処は，60万ドルで 3 ブロジェクトを 3 年支援する のが限界であった。）このプロジェクトの完成で，織維 一貫製造システム（パイプラインシステム；FTARシス テム）が如何に重要な概念であるかが証明され，同時に 大学が学際的な研究チームを組織し，大きな研究プロジ エクトを協同で遂行できることを示すことになった。企 業での CRAFTM の評価は高く，大学も企業にとって重 要な研究プロジェクトを企面し遂行する能力があると企 業が認める結果になった。特に，学際的な研究チームを 組織することが、複雑な問題を解く键になる。

1992年には，CRAFTMの基金はゼ口になる。しかし， CRAFTM の概念が全国縺維センター構想に膨らんでい った。全国雗維センターは1991年に設立され，タイミン グよく1992年に最初の研究基金を受けた。全国䄉維セン ターを設立するに当たってのビジョンは，「信頼できる， 生産性の高い, 高品質指向の䄉維産業を発展させること によりダイナミックな世界規模の市場に対抗できる産 業にする。ことである。ここで注目すべきことは，全 
国桟維センターは大学のブロジェクトであるにも拘らず， 大学に関する記述はない。そのビジョンは企業の将来像 について云々しているだけである。ビジョンがあれば，

ミッション (使命) がある。全国織維センターの使命と は、「米国械維産業が将来に渡って存続し競争力を保方 続けるための研究基盤を与える。」ことである。

全国蛓維センターは，アーバーン大学 (アラバマ州), クレムソン大学 (南カロライナ州), ジョージア工科大 学 (ジョージア州), ノースカロライナ州立大学 (北力 ロライナ州) の 4 大学がメンバーになっている。この4 大学はいずれも米国の南東部に位置し，500マイルの距 踓籍囲内にある。更に重要なことにこの 4 大学で米国

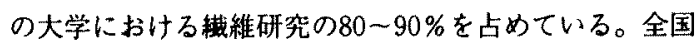
䑾維センターは，建物でも場所でもなくこのメンバー の大学間でスタッフ，学生を交換し，装瞋・設備を相互 利用することにより，窚維企業が共通して関心を示して いる研究・教育の目的を達成することである。全国械維 センター設立以前はこの 4 大学が協同研究，学生交換を 行った経験はなかった。企業は，この 4 大学協同作業を 非常に好意を持って受けとめたし，また長年待ち望んで いたことでもあった。

全国緉維センターは3つのゴールを持っている。第一 に，研究に扔いては，「斬新で先進的な製造プロセスの 開発と，現代織稚産業成功の鍵を握る統合システムの開 発・デザイン。」であるが、ここにいう「䄉維の研究」 とは，素材である高分子から稀消学、ビジネスといった 流通部門までの織維産業全体に関する研究を意味する。 第二に，教育においては，「人材育成，企業教育、紻䌖 工業コンプレックスが開発した先端技術を使いこなすた めの技術移行。」であり，4大学がともに「土地基金大

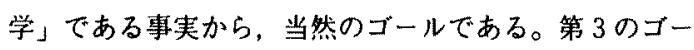
ルは，「全国峨維センター」の下に始まった協力関保を 確共にし，强化することである。つまり，「各地に分散 した尃門家，設備・装置を共通した目的の下に共同研究 プロジェクトに結集し、米国全土の織維研究・教育を強 化する。」

ある米国企業の最高賛任者は，「全国鐵維センターは， 米国における産学共同のあり方を示すモデルである。

(The National Textile Center is a Role Model for America)」といっている。この言莱は，広く新聞等に 引用され，全国桟維センターのスローガンになっている。 現在全国䄾維センターでは35の研究プロジェクトが遂行 されている。その分野は, 物質科学(高分子科学を含む

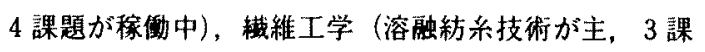
題), 紡績工学 ( 3 課題), 布帛工学 (7 課題), 染色・ 仕上代工学 (8課題), 艇製工学 (1 課題)，インテリジ
エントシステム工学（コンピューター統合製造システム 開発，5課題），市場調查 (消算者動向，クウィックレ スポンス等，4課題）と多岐に渡っている。この35のフ ロジクトはいずれもメンバーの2大学以上が関与して おり，複数の教官，学生が従事している。大体どのフロ ジェクトも，5，6名の教官とそれと同数以上の大学院 学生がチームを組んでいる。赛際には，108名の教官が 全国織維センターに係わっており，その専門分野も，械 維工学, 樴維化学, 械維・アバレル経営, 啔維物質科学, 機械工学, システム工学, 統計学, 心理学, 計算機科学, 消费科学、マーケティンク，等多彩である。この様に， いろいろな分野の専門家が共通した研究プロジェクトに 参加することは，いままで余り例がなかったことであり， 全国桟維センターの重要な特徵の一つである。

全国嬂維センターは，組織図（図 1) 加分かるよう に非常に奇妙な組織をとっている。運営幹部

(Operating Board) は各大学の傤維学部長で構成され ている。運営幹部は 2 名の盞維企業最高責任者により構 成される監查役 (Oversight Committee) の助言を受ける。 監查役の助言は，センターのあり方，センター・企業の 関係, センターの経営戦術等, 主としてセンターの運営 方針に関するものである。技術政問団（Technical Advisory Committee）は倳維企業の研究所所長により構 成されており，研究プロジタトの評洒を行う。各年度 毎に, 研究プロジェクトの新規探択, 継続, 予算䫓の決 定を行う。ディレクターはセンターの行政の長で,デュ ポンを引退したJ.カニングが現在その任にある。その 事務空はカニング氏の自宅にあり，仕事は基金の調達, 報告書作成, 研究助言で, 主として電話, ファクス, 電 子メイルで行っている。メンバーの各大学には地区ディ レクター（Site Director）がおり（例えばブッキ+ナン 教授はノースカロライナ州立大学の地区ディレクターで

\section{The National Textile Center Organization}

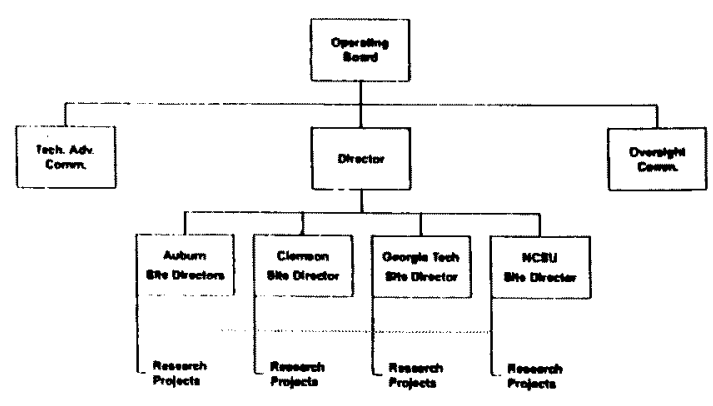

因1全国桟維センター組織図 
ある)，研究プロジェクトを管轄しているが，研究ブロ ジェクトは各大学にまたがっており，地区ディレクター の管轄は重なり合うことになる。

以上述べたように，全国栈維センターは，それといっ た場所があるわけではなく，研究プロジェクトの集合で ある。その研究プロジェクトは，メンバーの 4 大学の教 官が共同でそれぞれの装置・設備を使用して遂行する。

全国辖維センターは米国商務省の予算を得ている。七 ンターは完全に合䇐国予算で運営されており，企業の基 金は入っていない。しかし，研究プロジェクト遂行に当 たっての企業の知的，実際的な奇与は計り知れないもの がある。かなりの数の企業の人が, センターの運営の為 に時間・労力を割いている。センターで稼働中の各研究 プロジェクトは，企業のプラントに移行できる可能性を 持っている。そのための試行は企業の協力なしには出来 ない。

予算は年間 8 百万ドル（1992年から1994年の3 年平 均）で，各年度毎に決定される。全国諓維センターは， 企業と大学から姐何に双方にとって有益な研究プロジェ クトを設定し，協同で運営できるかを示すよい例である。 センターのプロジェクトの結果から, 大学における伝統 的な活動と同様に，学生は卒業論文を，教宫は発表論文 を作成する。企業にとっては，このプロジェクトの結果 は，後に企業に移行し応用プロジェクトに発展する研究 基礎として興味がある。因みに，今年度の予算の内百万 ドルは技術移行に関するプロジェクト用である。

\section{AMTEX}

最後に，米国における産官学協同の新しいあり方とし て, AMTEX に付いて述べる。AMTEX は䄉維関連企業 連合，全国襶䧽センターを含む5つの非営利樴維関連研 究機関，米国エネルギー省に属する国立研究所（ロスア ラモス，フルックヘイブン等を含む10研究所）のジョイ ントベンチャーで，全国織維センターの成功に触発され て生まれた。

ソ連崩壊に伴い，防衛費削減が始まった。第二次大戦 後に設立されたエネルギー省の国立研究所は武器開発が その主な目的であったが，その目的を一般企業向き研究 開発に変更することを余儀なくされた。エネルギー省が 先ず候補として挙げだ企業が械維関連企業である。これ は全国䄉維センターの成功例があり，且つヒンターで稼 動中のプロジェクトが国立研究所が参加するテーマとし て適当であると判断したためである。

AMTEX は，エネルギー省の10研究所と，非営利の 5 械維関連研究機関との間に結ばれた研究・開発に関する 協定であり，研究基金を供給する組織ではない。
AMTEX は技術開発，技術移行を目的とする組織で，研 究費はそれぞれの参加研究機関が独自に調達する。 AMTEX は従って全国峨維センターと相補う関係にある。 全国轿維センターは基整研究をその目的にしているが, AMTEX 岵技術移行・技術開発を促進する機関である。 AMTEX は産官学協同のモデルと見なされている。そ の設立の主旨には，「企業への技術移行を促進する。複 数研究機関にまたがる研究を調整する。大学をパートナ 一に加える。」ことが誢われている。現在では, AMTEX はまだ計画の段階であり，具体的な作業は始ま っていない。1994年度には 2 千5 百万ドルのエネルギー 省の予算が国立研究所に割り当てられ，4つの技術分野 の研究プロジェクト (1)分析，シミェレーション，シス テム化，(2)プロセス改良，素材開発，(3)自動化，(4)省工 ネルギー，㻴境問題，廃亲物对策）がスタートする。2 千5 百万ドルは，全国就維センター年間予算の䄪 4 倍に 相当する。9つのプロジェクトが計画中で，1994年度に は，100名以上のエネルギー省に属する科学者, ならび に75から100の企業メンバーがこのプロジェクトに参加 する事になる。プロジェクトとしては，(1)需要主体の製 造（クウィックレスボンス；予算10.4百万ドル，30企業 メンバー)，(2)コンピューターによる布帛評価（布帛欠 陥の検出を含む；予算3.7百万ドル，10企業メンバー)， (3)アパレル迅速製造用センター（プロセス制御用センサ 一等; 予算1.4百万ドル)，(4)迅速裁断（予算 2.0 百万ド ル，15企業メンバー)，(5)パレルパーッの自動同定 (予算1.3百万ドル，10企業メンバー），6環境に優しい プロセス開発（予算1.2 百万ドル，10企業メンバー）, (7)各ステップのプロセス改良（予算0.9百万ドル，15企 業メンバー)，(8)原料回取（子算0.9百万ドル，企業メン バー数末定)，が1994年度中に開始される。

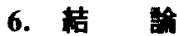

全国樴維センターの設立, AMTEXの組織化から明ら かなように，合采国政府は樴維企業を非常に重要な産業 だと考えている。1980年代の米国では，挠維産業は盛り の過ぎた古い技術の産業だと見なされていた。この2， 3 年に, 械維産業は米国の释済にとって非常に重要な産 業であることが再認識され，先端技術産業であり，適当 な研究組織を確立することにより更に前進する産業であ ることを証明した。政府より械維関連の研究資金を得る ことが容易になったし，政府関連の大型研究プロジェク トの計画立案に参画するよう求められるようにもなった。 この事実は，単に縺維関連大学にプラスになっただけで はなく、械維関連企業にもそのパプリックイメージを一 新する事に役立っている。 
どの国に於いても桟維関連分野の産学協同が必要であ る。冒頭でも述べたように，産学の価值観の違いから， 産学協同は一般に困難であるが，それぞれが近づく努力 をする価值がある。産学協同がうまくいくためには，(1) 互いの価值観を理解し，尊敬し，(2)共同作業に当たって は柔軟に対応し，(3)それぞれのパートナーの長所, 弱点 をよく知る，必要がある。

大学は，色々な専門的角度加 (学科・学部の壁を越 えて）問題に対処する必要があり，基碳研究と応用研究 の役割の違いを理解し，受け取った研究基金に見合う価 値ある結果を生み出す努力をしなければならない。企業 は，大学の法的，歴史的な制約を知り，現実的なレベル で大学の研究活動の資金援助をし，学生の教育の重要 を認識しなりナればならない。企業の抱える問題は複雑で
あるから，個人、個人の教授に対する研究費補助はあま り効果的ではない。企業が大学は学生を使って危険な研 究を安くやってくれるところた，と考えるのは間違って いる。企業は大学の研究の価值をもっと認める必要があ る。大学の既存の装置・設诵を使用することによる表に 現れない研究費を考虑すべきである。学生は大学が生産 する最も優れな製品であり，企業の将来は大学が送り出 す学生の質にかかっている。

結論として，双方でとってプラスになる産学協同は可 能である。米国で成功した産学協同例を述べた。文化， 歴史の違いから，米国の方式がそのままいずれの国でも 成功するとは思わない。しかし，日本においても、ここ で述べた産学協同の原理がその実施に際して応用できる と信じる。

贊助会員入会社 (1社1口)

株式会社 カインドウェア

正会員入会者 (25名)

\begin{tabular}{|c|c|c|c|}
\hline & 紹介者 & & 紹介者 \\
\hline 村崎 囊雄（帝京大） & & 恵美 和昭 (東洋蜍フフッションブラニンタ) & \\
\hline 渡辺 正一（日本ペイント） & & 松本 定喜 (日本毛織) & \\
\hline 佐藤 恭三（東北学院大） & & 角田 潔和（東京農業大） & \\
\hline 勝間 敬太（鋰紡） & 市橋 邦大 & 增田 依子 (大阪女子学園短大) & \\
\hline 尾上㕕(鐘紀) & & 岩溯 俊行 (鐘紡) & \\
\hline 嶋田由美子（群馬消費生活センター） & & 船阔 正光 (三重大) & \\
\hline 上原徹（島根大） & & 三好 明 (京工緎大) & 松本喜代一 \\
\hline 大崎 幸彦（大阪府貔） & & 森 益一（中日本織維工協組） & \\
\hline 西田 右広（東洋紡） & & 西村 弘 (ユニチカ) & 望月 政嗣 \\
\hline 村上 良一（熊本工大） & & 大谷 慶人 (高知大) & \\
\hline 今林 裕子（福岡女大） & & 高橋修二（横浜ゴム） & \\
\hline 舟榶 弘幸 (名I大) & & 谷口貞司（日本スピンドル製造） & 小西 \\
\hline 松村 修（松村内外特許） & 佐々木清文 & & \\
\hline
\end{tabular}

\section{学生会員入会者 (7名)}

\begin{tabular}{|c|c|c|c|}
\hline & 紹介者 & & 紹介者 \\
\hline 利山 光䄫 (北海道大) & 戸倉 清一 & 星熙（東大生研） & 瓜生 敏之 \\
\hline 中村 仁 (山形大) & 増子 & 敦（静岡大） & 稻垣 訓考 \\
\hline 浩（岡山大） & 横山 文義 & 牧野 守秀 (静岡大) & " \\
\hline 諸星 勝己（東工大） & 鞠谷 雄士 & & \\
\hline
\end{tabular}

